\title{
The possible role of local air pollution in climate change in West Africa
}

\author{
Peter Knippertz ${ }^{\star 1}$, Mat J. Evans ${ }^{2}$, Paul R. Field ${ }^{3,4}$, Andreas H. Fink', Catherine Liousse ${ }^{5}$ \\ and John H. Marsham ${ }^{6}$
}

\begin{abstract}
The climate of West Africa is characterized by a sensitive monsoon system that is associated with marked natural precipitation variability. This region has been and is projected to be subject to substantial global and regional-scale changes including greenhouse-gas-induced warming and sea-level rise, land-use and land-cover change, and substantial biomass burning. We argue that more attention should be paid to rapidly increasing air pollution over the explosively growing cities of West Africa, as experiences from other regions suggest that this can alter regional climate through the influences of aerosols on clouds and radiation, and will also affect human health and food security. We need better observations and models to quantify the magnitude and characteristics of these impacts.
\end{abstract}

\footnotetext{
$\mathrm{T}$
} he West African monsoon is one of the most important large-scale atmospheric circulation systems in the tropics. It controls winds, temperature, clouds and most importantly precipitation over a land area of about $6 \times 10^{6} \mathrm{~km}^{2}\left(\sim 5-25^{\circ} \mathrm{N}, 15^{\circ} \mathrm{W}\right.$ to $15^{\circ} \mathrm{E}$ ) and has remote impacts, for example through hurricane genesis. Through water resources, agriculture and power generation, the health and livelihoods of hundreds of millions of people depend on monsoonal rainfall.

The West African monsoon is a sensitive system that can be perturbed by different factors across a wide range of scales. A prominent example is the devastating drought in the 1970s and 1980 $\mathrm{s}^{1}$ that most severely affected the Sahel, one of the regions with the largest precipitation variability worldwide. A large fraction of decadal-scale rainfall variability in the West African monsoon area is explained by variations in Atlantic sea-surface temperatures, which have been linked to natural oscillations but also to changes in anthopogenic aerosol emissions during the twentieth century, predominantly from industrialized areas in the mid-latitudes ${ }^{2,3}$. It is anticipated that the West Africa regional climate will change because of the effects of global-scale warming, implying an increased likelihood of unprecedented heat waves and a threat to low-lying, densely populated coastal areas from sea-level rise ${ }^{4}$, and also because of land-use and land-cover change, as the increasing transformation of rain and savannah forests into agricultural land creates changes in the surface energy and water balance through effects on albedo, evapotranspiration, water transport and storage as well as surface roughness ${ }^{5,6}$.

Studies on the Indian and East Asian monsoons suggest that anthropogenic emissions of aerosols and aerosol precursor gases from these densely populated and increasingly industrialized areas can affect the amount and seasonality of rainfall. Earlier studies concentrated on scattering aerosols such as sulphates, which reduce monsoonal circulation and precipitation through a reduction of short-wave radiation reaching the surface, sometimes termed 'solar dimming ${ }^{7}$. The inclusion of absorbing aerosols such as black carbon creates a more complicated response in models that, among other things, depends on whether a coupling to the ocean is taken into account ${ }^{8}$. According to the 'elevated heat pump' concept, aerosol heating over the Tibetan Plateau causes large-scale circulation changes over South and East Asia ${ }^{9}$, but this idea is difficult to prove from observation $s^{10}$. Recent studies are increasingly including effects of aerosols on clouds and typically find a reduction of monsoon-season precipitation through the combined effects of clouds and radiation changes ${ }^{11,12}$.

In West Africa anthropogenic emissions of aerosols and aerosol precursor gases have increased rapidly in recent years and are projected to keep increasing ${ }^{13,14}$. This is particularly the case for the explosively growing cities along the Guinea Coast, as illustrated by high aerosol optical thickness along the coastal strip in the satellite image shown in Fig. 1, particularly in the area of Lagos. In this Perspective we will discuss the question of whether this increasing pollution can be expected to perturb the sensitive West African monsoon system and thereby contribute to regional climate change in addition to the more established long-term factors global warming and regional land-use and land-cover change. In contrast to the Indian and East Asian monsoon, this emerging research topic has not received much attention and therefore the relative magnitude of this problem and possible interactions of different factors are unclear. Undoubtedly urban air pollution has already become a significant threat for human and ecosystem health across West African cities such that any regulatory actions could have multiple benefits. We will begin with a short overview of the meteorological conditions over West Africa followed by a discussion of anthropogenic aerosols and aerosol-climate interactions. Concrete steps needed to improve our understanding of the role of air pollution for the West African climate are given in the concluding section.

\section{The meteorology of West Africa}

The West African monsoon is associated with a marked seasonal cycle. From November to February most of the region is dominated by dry northeasterly winds from the Sahara. Clouds and precipitation are confined to the coastal strip, where the sea-breeze circulation brings in moister air and creates near-surface convergence. 
$3^{\circ} \mathrm{E}$

$4^{\circ} \mathrm{E}$
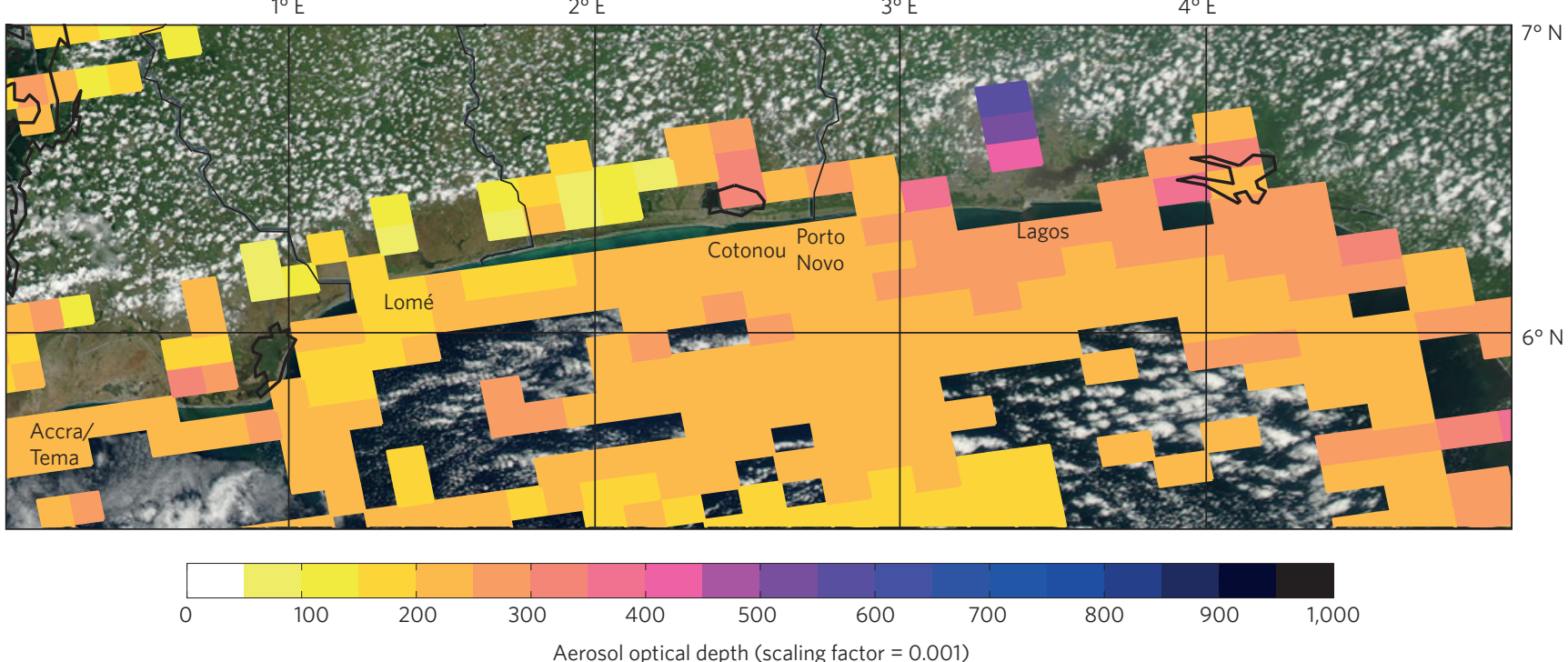

Figure 1| Sea breeze, clouds and pollution. MODIS visible image at 13:35 UTC on 12 October 2013 over southern West Africa showing a well-defined land-sea breeze and small-scale cumulus inland. MODIS aerosol optical depth at $0.55 \mu \mathrm{m}$ wavelength is overlaid as colour shading in areas where the retrieval algorithm96 determines the image to be sufficiently cloud-free. This product shows enhanced air pollution along the coast and over the Gulf of Guinea, particularly in the vicinity of the coastal cities marked.

Large amounts of mineral dust from the Sahel and Sahara are transported across the region, which in combination with humaninduced biomass burning lead to persistent haze because of the lack of wet removal. From March onwards the southwesterly monsoon winds begin to penetrate deeper into the continent, bringing with them moister air, more clouds and precipitation ${ }^{15}$. The monsoon retreats back to the southern parts of West Africa in September and October. At the peak of the wet season in July and August, the large meridional low-level pressure gradient between the cold seasurface temperatures in the eastern equatorial Atlantic Ocean and the Saharan heat low drives a strong monsoon flow with southwesterlies reaching about $20^{\circ} \mathrm{N}$ (Fig. 2a). The reduction in turbulence and therefore depth of the frictional layer from day to night leads to the formation of strong nocturnal low-level jets ${ }^{16-18}$ (Fig. 2b) that transport moist air far into the continent.

A complex meridional pattern of different types of clouds, usually with a marked diurnal cycle, is observed across West Africa during the wet season ${ }^{19,20}$. Around $15^{\circ} \mathrm{N}$ long-lasting, organized convective systems favoured by the shear provided by the African easterly jet generate the bulk of annual precipitation ${ }^{21,22}$. Maximum rainfall and the deepest ascent is usually found around $11^{\circ} \mathrm{N}$ (Fig. 2a). The Guinea coastal zone is characterized by locally initiated, less organized and often long-lasting convection during the afternoon and evening, for example associated with the land-sea breeze circulation $^{22-24}$ (evident from the cloud-free coastal strip in Fig. 1), and shallow warm-rain showers forming in the deep monsoonal layer (red shading in Fig. 2a). One striking feature in this region is the extensive coverage of mostly non-precipitating low stratus clouds related to the nocturnal low-level jet ${ }^{25-27}$. Dynamical controls on these clouds are subtle, with competing effects from temperature and moisture advection, radiative cooling, condensational heating, subcloud evaporation, the sea-breeze circulation and the gentle upslope flow ${ }^{28}$ (Fig. 2b). The stratus decks typically lift and break up in the course of the day to form more isolated cumulus ${ }^{20}$. Shallow mid-level layer clouds, sometimes caused by detrainment from convection, also frequently affect large parts of West Africa (Fig. 2a), but factors controlling their depth, extension and lifetime are not well understood. The combined radiative effect of these clouds has a strong impact on the surface energy balance ${ }^{29}$ and thus on the diurnal cycle of the boundary layer and ultimately initiation of convection. During the wet season, natural aerosol contributions include dust from the Sahara, often found at mid-levels associated with the northerly return flow (Fig. 2a), marine aerosols near the coast and biogenic aerosols further inland. The enhanced precipitation activity leads to a more effective wet removal of aerosols during this season.

\section{Anthropogenic aerosols}

Much of our current understanding of the regional atmospheric composition over West Africa stems from the African Monsoon Multidisciplinary Analysis (AMMA) ${ }^{30}$ project $^{31}$ and other activities such as the DECAFE (Dynamique et Chimie Atmosphérique en Forêt Equatoriale) programme, the IGAC (International Global Atmospheric Chemistry)/DEBITS (Deposition of Biogeochemically Important Trace Species)/AFRICA atmospheric chemistry and deposition monitoring network IDAF (http://idaf.sedoo.fr; in operation since 1995) and the Aerosol Robotic Network (AERONET) ${ }^{32}$. The bulk of this work, though, focused on the substantial natural emissions from deserts, soils, forests and oceans, and thus on more remote parts of the region. This pertains to both observations and modelling.

In West Africa, biomass burning is a large direct source of carbonaceous aerosols, which have a strong radiative effect, and also of volatile organic compounds, oxides of nitrogen, carbon monoxide and so on, which can indirectly impact climate through perturbing ozone and methane concentrations and through creating secondary aerosol particles. Biomass burning occurs predominantly during the dry season. It is almost exclusively anthropogenic following century-old traditional practices ${ }^{31,33}$.

An additional factor that has received surprisingly little attention thus far is anthropogenic emissions of domestic, traffic and industrial pollutants. Although the increase of the global population is slowing down, the population of West Africa continues to increase by $2-3 \%$ per year (Fig. 3), with the current population of around 340 million projected to reach more than 800 million by the middle of the century ${ }^{34}$. This increase is accompanied by strong economic 


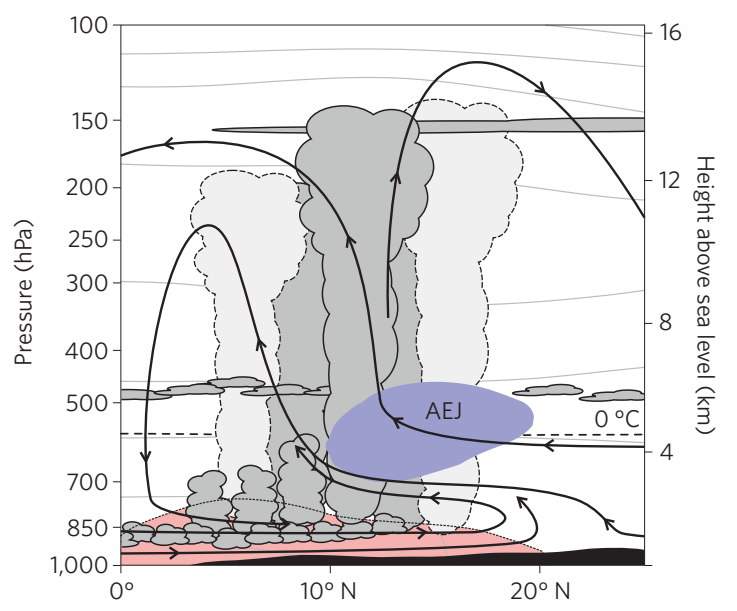

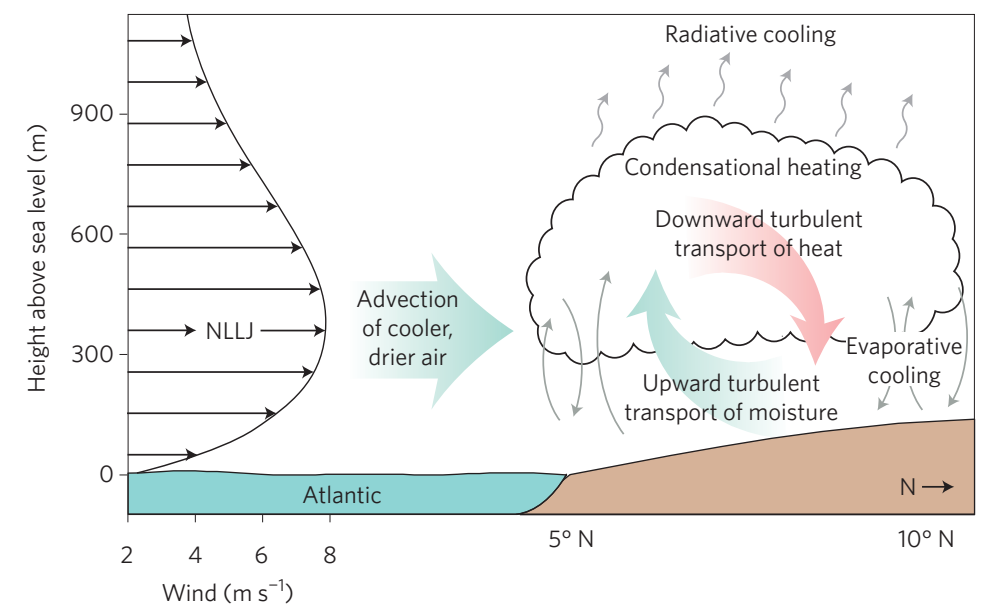

Figure 2 | Clouds and the West African monsoon. a, Schematic meridional-pressure section illustrating the West African monsoon circulation, main cloud types (dark grey for frequent and light grey for less frequent occurrence), moist monsoonal layer characterized by southwesterly winds (red shading) and the African easterly jet (AEJ, blue shading). Grey lines are isentropic surfaces; the $0^{\circ} \mathrm{C}$ isotherm is marked. $\mathbf{b}$, Zoom into the processes involved in the formation and maintenance of low-level stratus decks over southern West Africa. Vectors show a typical vertical profile of horizontal wind; NLLJ indicates the nocturnal low-level jet. This figure is derived from high-resolution modelling ${ }^{28}$. Panel $\mathbf{b}$ reproduced with permission from ref. 28 , AMS.

growth of currently about $5 \%$ per year, as well as industrialization and rapid urbanization (Fig. 3). As a result, pollutants such as oxides of nitrogen and sulphur, hydrocarbons, carbon monoxide and carbonaceous aerosols have increased sharply over the past decades and, depending on compound and scenario, are projected to increase between two- and fourfold by 2030 (Fig. 4a). They would then contribute between about 5 and $60 \%$ of global emissions, depending on compound and scenario ${ }^{13,14}$. A significant source of uncertainty in these predictions lies in the degree of regulatory constraint on emissions anticipated by the different West African countries over these decades.

A limited number of small-scale observational studies in West African cities, such as POLCA focusing on Dakar and Bamako, suggest that pollutants are already substantially above guidelines of the World Health Organization ${ }^{35-37}$. However, because of the lack of sufficient measurements, statistical information (for example, on fuel consumption) and regulatory activities, there are no emissions inventories for African cities (like those for London, for example, which currently have $30 \mathrm{~m}$ resolution). Given the short lifetime and thus spatial heterogeneity of many pollutants this makes estimating human exposure very challenging. It is notable from the limited studies that cities in West Africa suffer from a wide range of anthropogenic pollutants, some of which are also currently found in European cities (typically associated with high-temperature combustion such as particulates, nitrogen dioxide $\left(\mathrm{NO}_{2}\right)$ and ozone), but some that have not been a problem for many decades (associated with low-temperature combustion, evaporative sources and others such as organic carbon particles, carbon monoxide, benzene, polyaromatic hydrocarbons and heavy metals).

In terms of regional anthropogenic emissions, global inventories $^{13}$ provide some basis, but these suffer from coarse spatial resolution (typically $1^{\circ}$ ) and lack of West African specificities of both sector activity (cars and motorbikes, fire wood, charcoal production, animal waste usage, generator usage, population density and so on) and emission factors (compound-specific emissions per kilogram of fuel used by a car, a stove or in-house burning, for example). Recently, continental-scale emissions inventories have been created at $25-\mathrm{km}$ spatial resolution based on African-specific fuels and activities $^{14}$ (Fig. 4a), for example two-wheeled taxis ${ }^{38}$ (Fig. 4b). These show the importance of domestic fires for black carbon, organic carbon, carbon monoxide and volatile organic compounds; of cars for nitrogen oxides; and of industry for sulphur dioxide. Nevertheless, substantial uncertainties remain. The limited observationally based assessments of emissions for a city such as Lagos have historically not compared well with the coarser-resolution emission estimates ${ }^{39}$, but such comparisons are few and far between. In addition to urban emissions, the rapid development of the oil industry along the Guinea Coast, and its associated emissions and flaring, is an increasing source of anthropogenic pollution (ref. 40, and T. Doumbia, personal communication).

Once emitted, anthropogenic primary pollutants can build up regionally (10-1,000 km scale) and interact with other man-made (biomass burning) or natural emissions (from vegetation, exposed soil, lightning) (Fig. 5). Chemical processes typically driven by sunlight can transform this complex mix of pollutants to produce secondary compounds such as ozone, acids $\left(\mathrm{H}_{2} \mathrm{SO}_{4}, \mathrm{HNO}_{3}\right)$ and low volatile organics, which are harmful to humans and plants with potential impacts on agricultural productivity, and notably produce aerosol particles, which impact both health and climate as discussed in the next section.

Interactions between the increasing anthropogenic emissions and the large natural emissions still pose unresolved questions. The role of the naturally emitted isoprene and monoterpenes on regional ozone is well documented for regions such as the southern United States ${ }^{41}$, and our scientific understanding of this chemistry is evolving rapidly ${ }^{42-44}$, but studies assessing the situation for West Africa are few ${ }^{45,46}$. The impact on aerosols is even less clear. Secondary organic aerosols are formed from predominantly naturally emitted carbon compounds from trees, but there appears to be a significant yield enhancement from anthropogenic emissions. This may be because the anthropogenic emissions enhance the oxidant concentrations or change the volatility of the oxidation products, but this is still subject to significant research ${ }^{47}$. Observations from AMMA during the wet season show low organic mass concentration in West Africa despite significant biogenic emission ${ }^{48}$.

Oxides of nitrogen $\left(\mathrm{NO}_{x}\right)$ have both natural and anthropogenic sources and play a central role in the chemistry of the atmosphere. Globally their emissions are dominated by human activities. For West Africa, however, the anthropogenic source (traffic, domestic fires, industries and power plants) is relatively small compared with 


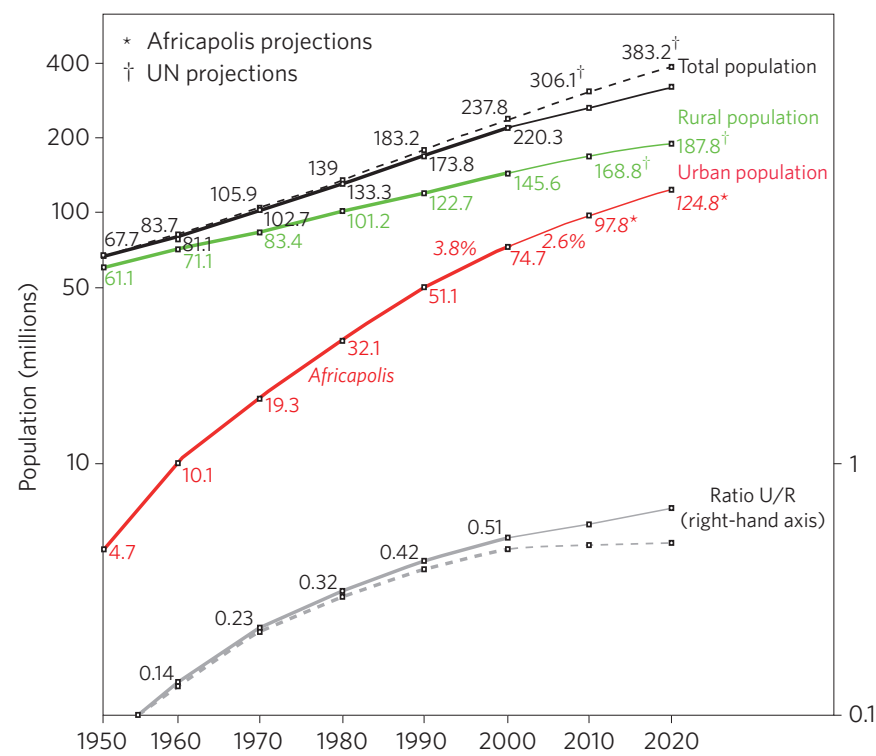

Figure 3 | Trends in West African population and settlement patterns.

Dashed black line: estimates and growth projections of the region's total population between 1950 and 2020 (ECOWAS member states plus Mauritania) taken from United Nations (UN) data. Red line: urban population according to the Africapolis study based on analysis of satellite/ aerial images and census data. Figures in italics indicate average annual increase for that decade. Green line: rural population according to official estimates. Solid black line: sum of red and green lines, showing possible disagreement with UN estimates. Grey lines give ratios of urban to rural $(U / R)$ population for the two different estimates. Note semi-logarithmic scale. Figure adapted with permission from ref. 97, SWAC/OECD.

the natural source, mostly from soils and lightning. The magnitude of the latter, however, is highly uncertain and variable on daily, seasonal and interannual timescales ${ }^{49}$. The impact of the rapidly increasing anthropogenic $\mathrm{NO}_{x}$ emissions (Fig. 4a) on top of the large but highly variable and uncertain natural $\mathrm{NO}_{x}$ emissions is not clear ${ }^{14}$. Other interactions such as those between anthropogenically emitted compounds and mineral dust ${ }^{50}$ and ocean-sourced halogen $s^{51,52}$ are also highly uncertain and speculative.

Our understanding of the interactions between the natural and anthropogenic systems is made more complex given the anticipated impacts on the region's ecosystems from an increasing population, from land-use and land-cover changes, and from a changing climate. As with other regions, there is also an impact of long-range transport of pollutants into the area, for example from biomassburning plumes from southern Africa ${ }^{31,33,53}$.

\section{Aerosol-climate interactions}

Generally, aerosols affect climate through impacts on radiation and clouds. The physical understanding of direct radiative effects is comparatively good, but uncertainties are introduced through insufficient knowledge of the vertical distribution and optical properties of the particles that depend on size distribution, shape and chemical composition, whereas interactions between aerosols and clouds are less well understood - particularly for ice and mixedphase clouds $\mathrm{s}^{54,55}$ - and remain one of the most uncertain anthropogenic forcings of the Earth's climate $e^{56}$.

For West Africa, most of the aerosol-climate interaction studies look at radiative effects of dust and biomass burning aerosols. Black carbon from man-made fires during the dry season has been suggested to reduce precipitation in West Africa by changing the atmospheric circulation, leading to reductions of cloud frequencies and height ${ }^{57}$. Similar impacts have been found from the radiative effects of desert dust ${ }^{58,59}$. Urban pollution can enhance downwelling radiation during clear nights and therefore cause large increases in night-time minimum temperatures as warm air is mixed from aloft because of radiative destabilization ${ }^{60}$, but this has not been investigated for the Guinea Coastal zone, where additional impacts on the nocturnal low-level jet and stratus formation can be expected ${ }^{26,28}$.

To the best of our knowledge, there are no studies looking into aerosol-cloud interactions over the moister southern parts of West Africa. This is partly due to a sparse network of measurements for atmospheric composition and meteorological variables ${ }^{61}$ and partly due to the historically low levels of industrial development. Aerosols directly affect the properties of cloud droplets and ice crystals, which then in turn affect cloud-top height, albedo, areal extent and lifetime, and the cloud's environment; that is, there are two-way couplings between the cloud's microphysical and macrophysical properties ${ }^{62-66}$. As a result, the effects of aerosols on single clouds can be very different from when a system of clouds evolving through many cloud lifetimes is considered. Such aerosol effects have barely been considered for the meteorological environment of the West African monsoon.

Previous research in regions affected by biomass burning ${ }^{67}$ has shown that the size distribution and number concentration of the aerosol particles are the main predictor of the concentration of cloud condensation nuclei (CCN), whereas composition and hygroscopicity are less important. However, secondary organic aerosols may play a role in complicating predictions of CCN concentration $^{68}$. Studies on the extensive marine stratus decks in subtropical high-pressure regions show that an increase in aerosols can lead to changes of up to $40 \%$ of the reflected shortwave radiation ${ }^{69}$ and can inhibit rainfall, with lightly precipitating clouds affected most severely ${ }^{70}$. In summertime West Africa, the nocturnal low-level jet carries pollution from the coastal belt inland, where interactions with biogenic emissions from fields and forests may lead to the formation of secondary aerosol particles as discussed above. These aerosols are likely to be mixed into the extensive low stratus decks over the region (see Fig. 2). It would therefore be interesting to investigate possible changes to the clouds' radiative effects ${ }^{71}$, which in turn could change the evolution of the boundary layer and consequently the diurnal cycle of convection ${ }^{72}$. Changes to the areal cover, longevity or brightness of the West African stratus clouds could then have an effect on surface radiation due to the albedo contrast with the underlying dark forest areas ${ }^{27}$. This may ultimately affect larger parts of the West African monsoon system through changes to the regional circulation. Unfortunately, current climate models seem to struggle with realistically representing both low- and mid-level clouds in this region, resulting in a spread of up to $90 \mathrm{~W} \mathrm{~m}^{-2}$ in the regional mean daily surface solar irradiance ${ }^{27,73}$. Couvreux et al. ${ }^{74}$ show that the cloud radiative errors are already established after a few days' simulation time and seem to be related to the complex local energy balances and boundary-layer processes rather than large-scale advection ${ }^{18}$. These errors may therefore be related to problems with the model parameterizations of convection and the boundary layer, demonstrating the challenge of realistically representing cloud-aerosol effects in this region in models.

For convective clouds, modelling studies have shown that aerosol effects are typically more important in situations with relatively low convective available potential energy ${ }^{75}$, as is often the case along the Guinea Coast. Detailed mechanisms have been proposed for single clouds, such as the concept of convective invigoration ${ }^{63}$ that links increased aerosol loading to deeper, more vigorous convection by chaining together a number of physical processes. However, breaks in that chain or differences introduced by considering additional physical processes such as entrainment, downdraft production and aerosol radiative interactions can even lead to suppression 

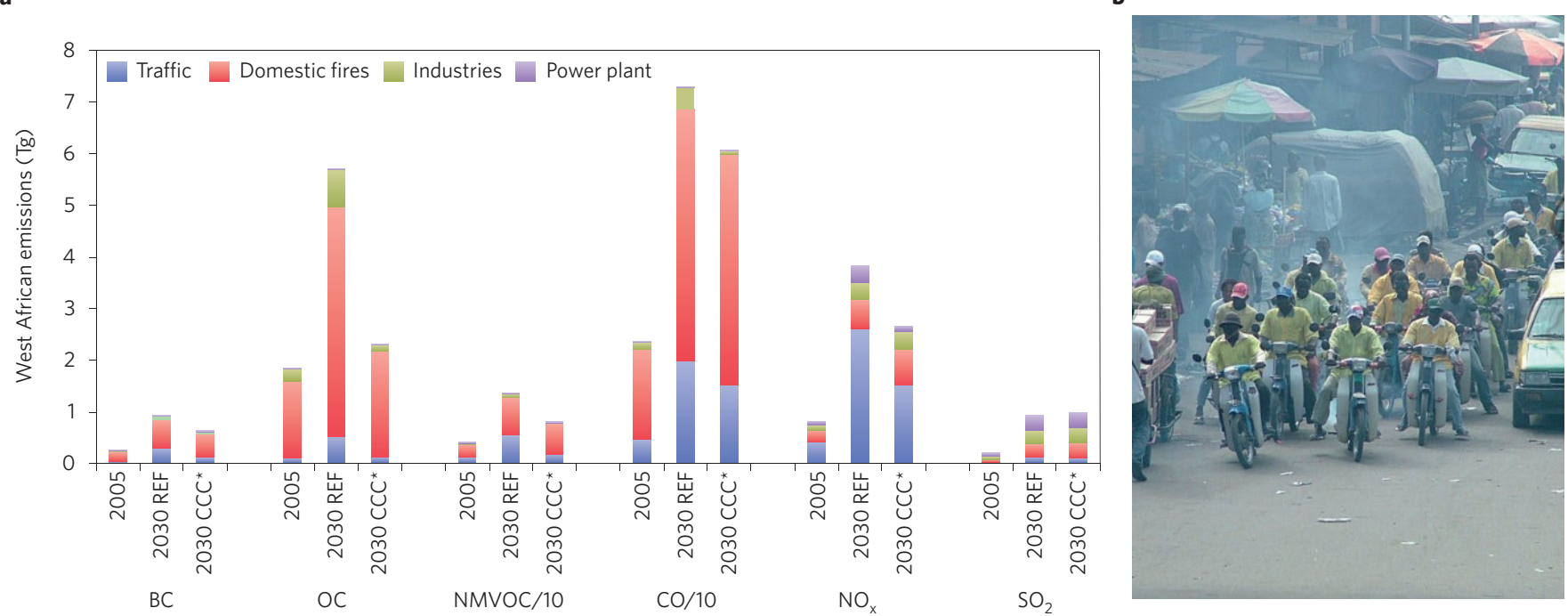

Figure 4 | Emission inventories and scenarios. a, West African emissions of black carbon (BC), organic carbon (OC), oxides of nitrogen ( $\mathrm{NO} \mathrm{x}_{\mathrm{x}}$ ) and sulphur $\left(\mathrm{SO}_{2}\right.$ ), non-methane volatile organic compounds (NMVOC) and carbon monoxide (CO). Emissions are shown for 2005, and projected emissions in 2030 for a reference (REF) scenario and for a 'carbon constraint case' (CCC) scenario, assuming Africa-specific regulations implemented to obtain a strong reduction of emissions resulting from incomplete combustion. Sector-activity relative abundances (traffic, domestic fires, industries and power plants) are indicated in each case. Data from ref. 14. b, A typical source of pollution in West African cities: two-wheeled taxis (photo courtesy of Benjamin Guinot).

of convection ${ }^{76}$. Again, ideas and results based on single clouds may not translate to results for cloud fields, because the evolution of the thermodynamics and aerosol environments is more complex and allows interactions between clouds to occur ${ }^{65}$. For example, some recent studies have shown that precipitation rates can be fairly robust to aerosol changes in some situations, even though the aerosols may still affect the microphysical and radiative properties of the clouds ${ }^{77,78}$. Nevertheless, changes to deep convective clouds from increased aerosol loads over West Africa have some potential to affect the distribution and intensity of precipitation, on which the population relies. These changes may modify the monsoon circulation through changes to tropospheric heating and by modifying upper- and mid-level clouds that are formed via detrainment ${ }^{79,80}$. Effects are likely to change as the character and organization of convection changes through the monsoon. None of these ideas has ever been tested for the polluted parts of West Africa.

\section{Future perspectives}

In many ways, the atmosphere above West Africa is still one of the least studied and understood on the planet, yet it plays a central role in determining the health and economic well-being of a large and increasing population. Given experiences in other densely populated monsoon areas in India and East Asia, we argue in this Perspective that more effort is needed to improve our understanding of the impact of air pollution on climate in West Africa and its importance relative to regional effects of global climate change as well as effects of landuse and land-cover changes. Progress is currently hampered by a lack of appropriate meteorological and compositional observations, and statistical information on emission patterns to enable research into the complex interplay between pollutants, their secondary chemistry and changes to meteorology and climate across a range of spatial and temporal scales.

Fully coupled chemistry-aerosol-climate models are needed to advance our process understanding, to estimate the importance of air pollution relative to other climate drivers and to assess impacts of different future scenarios and mitigation pathways. But substantial model errors still exist with respect to key features of the West African monsoon $^{81-83}$, leading to a lack of skill in seasonal prediction ${ }^{84,85}$ and to large intermodel spread and low confidence in climate projections, especially for precipitation ${ }^{86-88}$. Despite significant advances, for example as part of the $\mathrm{AMMA}^{30}$ project ${ }^{83,89,90}$, some well-known model errors remain, such as those associated with the radiative imbalance in the area of the summertime Saharan heat low over Mali and Mauritania ${ }^{91}$, the representation of deep convection in the Sahel and its effects on the monsoon ${ }^{79,80,92}$, air-sea interactions over the tropical eastern Atlantic Ocean ${ }^{93}$, and low- and mid-level cloudiness in southern West Africa ${ }^{27,73}$. Deficits in the meteorological models influence the simulated distribution of pollutants through transport, mixing and removal processes and therefore contribute to uncertainties in the coupled meteorology-chemistry system ${ }^{31}$.

To overcome these difficulties, several important steps are proposed:

- Refine emission inventories and scenarios. This requires a targeted source specification and key emission factor measurements, particularly for unique sectors such as West African oil exploration, traffic or waste burning. Better statistical data on aspects such as fuel consumption (vehicle fuel, wood, charcoal and others) are also needed to scale the measurements up to national level. Together these data should be fed into emission inventories and used for the development of future scenarios.

- Monitor air pollution. An extension of the existing network of long-term parallel observations of air pollution (with key atmospheric composition parameters in both the gas and aerosol phase) and epidemiological and biological studies at the source level in selected urban sites is needed for an assessment of health issues related to air pollution in addition to, for example, the rural IDAF network. Results from such assessments can demonstrate potential benefits from emission regulations on both health and climate.

- Improve availability of meteorological observations. This requires that observations of standard meteorological parameters (precipitation, cloud cover, temperature, humidity, wind and radiation) from existing networks, usually operated by national weather services, are made available to the research community more systematically and if possible in real time. This should also include 


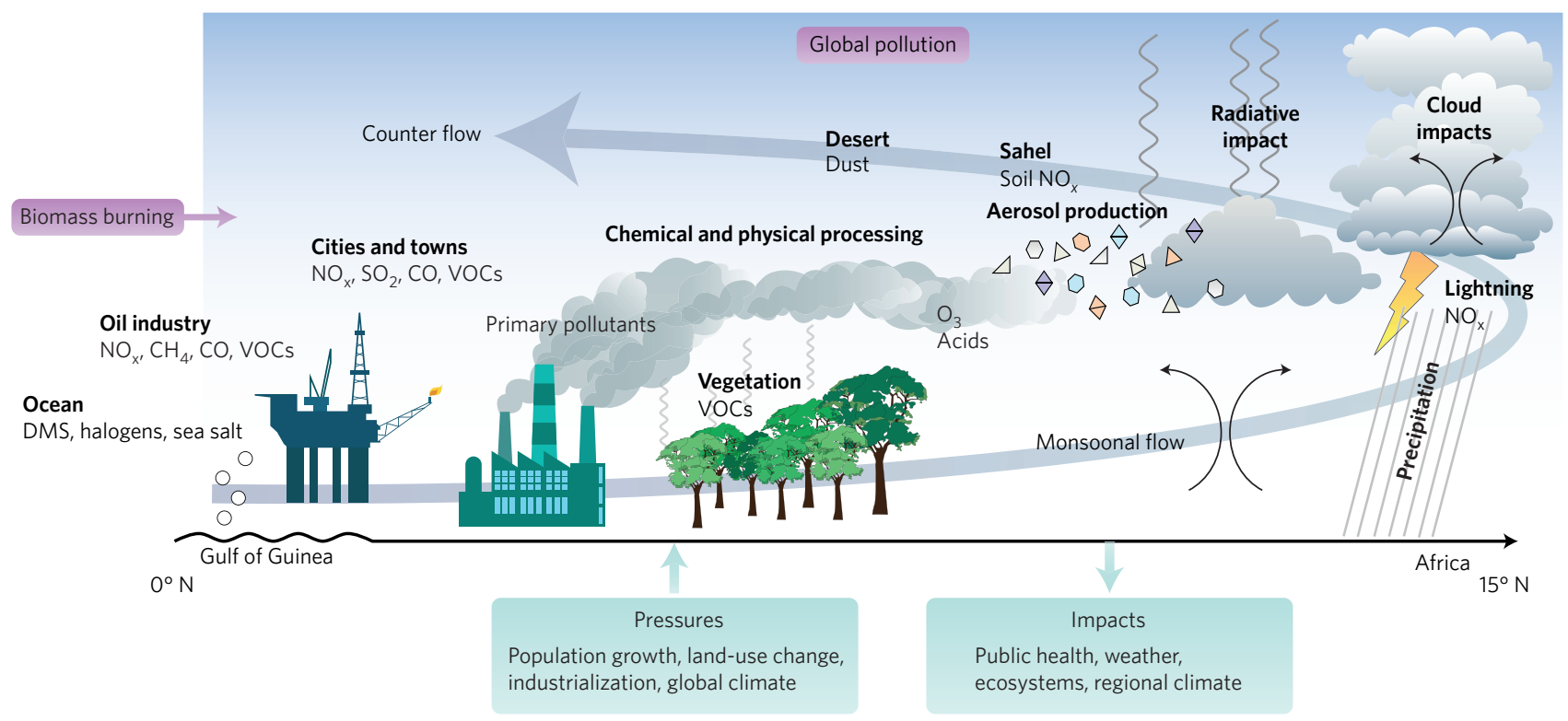

Figure 5 | Atmospheric chemistry and its impacts over West Africa. The schematic shows the main emission sources of atmospheric trace gases and secondary aerosols in a north-south transect through West Africa, including elements of long-range transport depicted as purple boxes. Boxes below the main diagram show the different pressures on this system from ongoing changes as well as their potential impacts on the regional scale. DMS, dimethyl sulphide.

upper-air information from radiosondes and pilot balloons ${ }^{94}$ and would ideally be accompanied by an enhancement of existing measuring capabilities, particularly of radiation, precipitation and clouds. Digitization of observational records only existing on paper would further enhance the data availability for long-term studies.

\section{- Conduct targeted international field campaigns in West} Africa. Sophisticated ground-based and airborne instrumentation for atmospheric dynamics (particularly diurnal evolution of the boundary layer and associated cloudiness), composition (particularly secondary aerosol formation from anthropogenic and biogenic emissions), cloud microphysics (characteristics of low-level liquid clouds and transition to deeper clouds) and radiation (both aerosol direct and cloud effects) should be employed. The data, together with models, should be used to reduce uncertainty in our understanding of the complex interplay between meteorology, atmospheric chemistry and clouds. Such a campaign is currently planned for June-July 2016 as part of the EU-funded 'Dynamics-Aerosol-Chemistry-Cloud Interactions over West Africa' (DACCIWA) project ${ }^{95}$.

- Enhance reliability of satellite data. Every remote-sensing product needs ground truth to assess its reliability. The lack of adequate surface-based observations in West Africa currently impedes a rigorous assessment of the quality of satellite products. The steps outlined above, together with an enhanced network of ground-based Sun photometers, would greatly increase the possibility of generating West-Africa-specific evaluations of satellite products and of improving existing and future retrievals. This should include both meteorological parameters (for example the new Global Precipitation Mission) and compositional parameters (for example the new high-resolution sensors on the Sentinel series of satellite missions, part of the European Space Agency's Global Monitoring for Environment and Security programme).

- Improve the representation of the West African monsoon system in numerical models. New and better observations should be used to evaluate and further develop coupled meteorological/atmospheric chemistry models used for predictions of air-quality, weather, seasonal and climate signals. This will require coordinated efforts from both academic and operational institutions, for example the IMPALA (Improving Model Processes for African Climate) project within the Future Climate for Africa (FCFA) programme. Recent developments in computing power are now enabling high-resolution simulations (around kilometre scales) to be performed over relatively large spatial domains for long periods. This allows all processes, from city-scale emissions of pollutants, to their chemistry, explicit resolving of cloud processes and the resultant impacts on meteorology, health, ecosystems and climate, to be examined seamlessly within a single model ${ }^{80}$. New developments in data assimilation including aerosol parameters also contribute to the identification and reduction of model errors. It is hoped that such studies can in the long run improve the representation of salient features of the West African monsoon. A specific target for southern West Africa should be the summertime low-level stratus and warm rain showers that we hypothesize here to be susceptible to aerosol effects.

- Assess future impacts and mitigation pathways. New and improved models should be used to investigate possible future changes in the West African environment related to global climate change, regional land-use and land-cover change, and local to regional anthropogenic emissions in an integrated way. These models should also be used to explore mitigation pathways, for example through West Africa-specific emission regulations.

- Build local capacity. This requires the training of the next generation of African climate scientists who will understand the complex interplay between natural and man-made, global and regional factors that affect the West African climate as well as socio-economic and political implications. A notable initiative in this direction, in addition to FCFA mentioned above, is the West African Science Service Centre on Climate Change and Adapted Land Use (WASCAL, www.wascal.org). 
The steps outlined above require increased efforts from the global climate research community to advance understanding of the multiple facets of the challenging problem of regional climate change in one of the most rapidly evolving regions of the world. Greater understanding should help to clarify the question of whether the steeply increasing short-lived anthropogenic constituents need to be considered for the more policy-relevant mid-term climate projection until the middle of the twenty-first century. The next significant challenge will then be to translate enhanced scientific understanding into policy reform on the city, regional, national and international levels. This can only work in collaboration with African partners such as academic researchers, national weather services and government organizations.

Received 25 August 2014; accepted 18 June 2015; published online 21 August 2015

\section{References}

1. Sanogo, S. et al. Spatio-temporal characteristics of the recent rainfall recovery in West Africa. Int. J. Climatol. http://dx.doi.org/10.1002/joc.4309 (2015).

2. Ackerley, D. et al. Sensitivity of twentieth-century Sahel rainfall to sulphate aerosol and $\mathrm{CO}_{2}$ forcing. J. Clim. 24, 4999-5014 (2011).

3. Booth, B. B., Dunstone, N. J., Halloran, P. R., Andrews, T. \& Bellouin, N. Aerosol implicated as a prime driver of twentieth-century North Atlantic climate variabil ty. Nature 484, 228-233 (2012).

4. Turn Down the Heat: Why a $4{ }^{\circ} \mathrm{C}$ Warmer World Must Be Avoided (World Bank, 2012).

5. Paeth, H., Born, K., Girmes, R., Podzun, R. \& Jacob, D. Regional climate change in tropical and northern Africa due to greenhouse forcing and land use changes. J. Clim. 22, 122-132 (2009).

6. Mayaux, P. et al. State and evolution of the African rainforests between 1990 and 2010. Phil. Trans. R. Soc. B 368, http://dx.doi.org/10.1098/rstb.2012.0300 (2013).

7. Boucher, O., Pham, M. \& Sadourny, R. General circulation model simulations of the Indian summer monsoon with increasing levels of sulphate aerosols. Ann. Geophys. 16, 346-352 (1998)

8. Chung, C. \& Ramanathan, V. Weakening of North Indian SST gradients and the monsoon rainfall in India and the Sahel. J. Clim. 19, 2036-2045 (2006).

9. Lau, K., Kim, M. \& Kim, K. Asian summer monsoon anomalies induced by aerosol direct forcing: the role of the Tibetan Plateau. Clim. Dynam. 26, 855-864 (2006).

10. Wonsick, M. M., Pinker, R. T. \& Ma, Y. Investigation of the 'elevated heat pump' hypothesis of the Asian monsoon using satellite observations. Atmos. Chem. Phys. Discuss. 13, 10125-10156 (2013).

11. Liu, X., Xie, X., Yin, Z.-Y., Liu, C. \& Gettelman, A. A modeling study of the effects of aerosols on clouds and precipitation over East Asia. J. Theor. Appl. Climatol. 106, 343-354 (2011).

12. Guo, L., Highwood, E. J., Shaffrey, L. C. \& Turner, A. G. The effect of regional changes in anthropogenic aerosols on rainfall of the East Asian Summer Monsoon. Atmos. Chem. Phys. 13, 1521-1534 (2013).

13. Lamarque, J.-F. et al. Historical (1850-2000) gridded anthropogenic and biomass burning emissions of reactive gases and aerosols: methodology and application. Atmos. Chem. Phys. 10, 7017-7039 (2010).

14. Liousse, C., Assamoi, E., Criqui, E. P., Granier, C. \& Rosset, R. Explosive growth in African combustion emissions from 2005 to 2030. Environ. Res. Lett. 9, 035003 (2014).

This paper provides an update on anthropogenic emissions across the whole of Africa including a scenario up to 2030.

15. Sultan, B. \& Janicot, S. The West African monsoon dynamics. Part II: The 'preonset' and 'onset' of the summer monsoon. J. Clim. 16, 3407-3427 (2003)

16. Lothon, M., Saï, F., Lohou, F. \& Campistron, B. Observation of the diurnal cycle in the low troposphere of West Africa. Mon. Weath. Rev. 136, 3477-3500 (2008).

17. Abdou, K., Parker, D. J., Brooks, B., Kalthoff, N. \& Lebel, T. The diurnal cycle of lower boundary-layer wind in the West African monsoon. Q. J. R. Meteorol. Soc. 136, 66-76 (2010).

18. Gonou, A., Guichard, F. \& Couvreux, F. Observations of diurnal cycles over a West African meridional transect: Pre-monsoon and full-monsoon seasons. Bound. Layer Meteorol. 144, 329-357 (2012).

19. Stein, T. H. M. et al. The vertical cloud structure of the West African monsoon: A 4 year climatology using CloudSat and CALIPSO. J. Geophys. Res. 116, 1-13 (2011).

20. van der Linden, R., Fink, A. H. \& Redl, R. Satellite-based climatology of lowlevel continental clouds in southern West Africa during the summer monsoon season. J. Geophys. Res. 120, 1186-1201 (2015).
21. Fink, A., Vincent, D. G. \& Ermert, V. Rainfall types in the West African Soudanian Zone during the summer monsoon 2002. Mon. Weath. Rev. 134, 2143-2164 (2006).

22. Fink, A. H., Paeth, H., Ermert, V., Pohle, S. \& Diederich, M. in Impacts of Global Change on the Hydrological Cycle in West and Northwest Africa, 135-149 (Springer, 2010).

23. Omotosho, J. B. The separate contribution of line squalls, thunderstorms and the monsoon to the total rainfall in Nigeria. J. Climatol. 5, 543-552 (1985).

24. Kamara, I. The origins and types of rainfall in West Africa. Weather 41, 48-56 (1986).

25. Schrage, J. M., Augustyn, S. \& Fink, A. H. Nocturnal stratiform cloudiness during the West African monsoon. Meteorol. Atmos. Phys. 95, 73-86 (2007)

26. Schrage, J. M. \& Fink, A. H. Nocturnal continental low-level stratus over tropical West Africa: Observations and possible mechanisms controlling ts onset. Mon. Weath. Rev. 140, 1794-1809 (2012).

27. Knippertz, P. et al. Ultra-low clouds over the southern West African monsoon region. Geophys. Res. Lett. 38, L21808 (2011).

This paper is the first to assess systematically the representation of the monsoon stratus over southern West Africa in climate models and satellite products.

28. Schuster, R., Fink, A. H. \& Knippertz, P. Formation and maintenance of nocturnal low-level stratus over the southern West African monsoon region during AMMA 2006. J. Atmos. Sci. 70, 2337-2355 (2013).

This paper is the first extensive modelling study concentrating on the processes involved in the formation and maintenance of the monsoon stratus cloud decks.

29. Bouniol, D. et al. Diurnal and seasonal cycles of cloud occurrences, types, and radiative impact over West Africa. J. Appl. Meteorol. Climatol. 51, 534-553 (2012)

30. Redelsperger, J.-L. et al. African Monsoon Multidisciplinary Analysis: An international research project and field campaign. Bull. Am. Meteorol. Soc. 87, 1739-1746 (2006).

31. Mari, C. H. et al. Atmospheric compos tion of West Africa: highlights from the AMMA international program. Atmos. Sci. Lett. 12, 13-18 (2011). This paper provides a broad overview of knowledge of the regional atmospheric composition over West Africa.

32. Holben, B. N. et al. AERONET - A federated instrument network and data archive for aerosol characterization. Remote Sens. Environ. 66, 1-16 (1998).

33. Liousse, C. et al. Updated African biomass burning emission inventories in the framework of the AMMA-IDAF program, with an evaluation of combustion aerosols. Atmos. Chem. Phys. 10, 9631-9646 (2010).

34. World Population Prospects: The 2012 Revision (UN Population Division, Population Estimates and Projections Section, 2012); http://esa.un.org/wpp

35. Baumbach, G. et al. Air pollution in a large tropical city with a high traffic density: Results of measurements in Lagos, Nigeria. Sci. Total Environ. 169, 825-831 (1995)

36. Doumbia, T. et al. Real time black carbon measurements in West and Central Africa urban sites. Atmos. Environ. 54, 529-537 (2012).

37. Val, S. et al. Physico-chemical characterization of African urban aerosols (Bamako in Mali and Dakar in Senegal) and their toxic effects in human bronchial epithelial cells: Description of a worrying situation. Particle Fibre Toxicol. 10, 10 (2013).

38. Assamoi, E. \& Liousse, C. Focus on the impact of two wheel vehicles on African combustion aerosols emissions. Atmos. Environ. 44, 3985-3996 (2010).

39. Hopkins, J. R. et al. Direct estimates of emissions from the megac ty of Lagos. Atmos. Chem. Phys. 9, 8471-8477 (2009).

40. Osuji, L. C. \& Avwiri, G. O. Flared gases and other pollutants associated with air quality in industrial areas of Nigeria: An overview. Chem. Biodivers. 2, 1277-1289 (2005)

41. Trainer, M. et al. Models and observations of the impact of natural hydrocarbons and rural ozone. Nature 329, 705-707 (1987).

42. Paulot, F. et al. Isoprene photooxidation: new insights into the production of acids and organic nitrates. Atmos. Chem. Phys. 9, 1479-1501 (2009).

43. Surratt, J. D. et al. Reactive intermediates revealed in secondary organic aerosol formation from isoprene. Proc. Natl Acad. Sci USA 107, 6640-6645 (2010).

44. Welz, O. et al. Direct kinetic measurements of Criegee intermediate $\left(\mathrm{CH}_{2} \mathrm{OO}\right)$ formed by reaction of $\mathrm{CH}_{2} \mathrm{I}$ with $\mathrm{O}_{2}$. Science 335, 204-207 (2012).

45. Williams, J. E. et al. The influence of biogenic emissions from Africa on tropical tropospheric ozone during 2006: A global modeling study. Atmos. Chem. Phys. 9, 5729-5749 (2009)

46. Marais, E. A. et al. Isoprene emissions in Africa inferred from OMI observations of formaldehyde columns. Atmos. Chem. Phys. 12, 6219-6235 (2012).

47. Spracklen, D. V. et al. Impacts of climate change from 2000 to 2050 on wildfire activity and carbonaceous aerosol concentrations in the western United States. J. Geophys. Res. 114, D20301 (2009). 
48. Capes, G. et al. Secondary organic aerosol from biogenic VOCs over West Africa during AMMA. Atmos. Chem. Phys. 9, 3841-3850 (2009).

49. Saunois, M. et al. Factors controlling the distribution of ozone in the West African lower troposphere during the AMMA (African Monsoon Multidisciplinary Analysis) wet season campaign. Atmos. Chem. Phys. 9, 6135-6155 (2009).

50. Tang, Y. et al. Impacts of dust on regional tropospheric chemistry during the ACE-Asia experiment: A model study with observations. J. Geophys. Res. 109, D19S21 (2004).

51. Parella, J. P. et al. Tropospheric bromine chemistry: implications for present and pre-industrial ozone and mercury. Atmos. Chem. Phys. 12, 6723-6740 (2012).

52. Sarwar, G., Simon, H., Bhave, P. \& Yarwood, G. Examining the impact of heterogeneous nitryl chloride production on air quality across the United States. Atmos. Chem. Phys. 12, 6455-6473 (2012).

53. Sauvage, B. et al. Tropospheric ozone over Equatorial Africa: regional aspects from the MOZAIC data. Atmos. Chem. Phys. 5, 311-335 (2005).

54. Hoose, C. \& Möhler, O. Heterogeneous ice nucleation on atmospheric aerosols: a review of results from laboratory experiments. Atmos. Chem. Phys. 12, 9817-9854 (2012).

55. Murray, B. J., O’Sullivan, D., Atkinson, J. D. \& Webb, M. E. Ice nucleation by particles immersed in supercooled cloud droplets. Chem. Soc. Rev. 41, 6519-6554 (2012).

56. Boucher, O. et al. in Climate Change 2013: The Physical Science Basis (eds Stocker, T. F. et al.) 571-657 (IPCC, Cambridge Univ. Press, 2013).

57. Huang, J., Zhang, C. \& Prospero, J. M. Large-scale effect of aerosols on precip tation in the West African Monsoon region. Q. J. R. Meteorol. Soc. 135, 581-594 (2009).

58. Konare, A. et al. A regional climate modeling study of the effect of desert dust on the West African monsoon. J. Geophys. Res. 113, D12206 (2008).

69. Solmon, F., Elguindi, N. \& Mallet, M. Radiative and climatic effects of dust over West Africa, as simulated by a regional climate model. Clim. Res. 52, 97-113 (2012).

60. Christy, J. R., Norris, W. B. \& McNider, R. T. Surface temperature variations in East Africa and possible causes. J. Clim. 22, 3342-3356 (2009).

61. Lebel, T. et al. The AMMA field campaigns: Accomplishments and lessons learned. Atmos. Sci. Lett. 12, 123-128 (2011).

62. Levin, Z. \& Cotton, W. R. Aerosol Pollution Impact on Precipitation: A Scientific Review (WMO/IUGG International Aerosol Precip tation Science Assessment Group, 2008).

63. Rosenfeld, D. et al. Flood or drought: How do aerosols affect precip tation? Science 321, 1309-1313 (2008).

64. Khain, A. P. Notes on state-of-the-art investigations of aerosol effects on precip tation: a cr tical review. Environ. Res. Lett. 4, 015004 (2009).

65. Stevens, B. \& Feingold, G. Untangling aerosol effects on clouds and precip tation in a buffered system. Nature 461, 607-613 (2009) Seminal paper on the challenge to understand cloud-aerosol interactions.

66. Tao, W.-K. et al. Impact of aerosols on convective clouds and precipitation. Rev. Geophys. 50, RG2001 (2012)

67. Rose, D. et al. Cloud condensation nuclei in polluted air and biomass burning smoke near the mega-city Guangzhou, China. Part 1: Size-resolved measurements and implications for the modeling of aerosol particle hygroscopicity and CCN activity. Atmos. Chem. Phys. 10, 3365-3383 (2010).

68. Topping, D., Connolly, P. \& McFiggans, G. Cloud droplet number enhanced by co-condensation of organic vapours. Nature Geosci. 6, 443-446 (2013).

69. Wood, R. et al. The VAMOS Ocean-Cloud-Atmosphere-Land Study Regional Experiment (VOCALS-REx): Goals, platforms, and field operations. Atmos. Chem. Phys. 11, 627-654 (2011).

70. Terai, C. R. et al. Does precipitation susceptibil ty vary with increasing cloud thickness in marine stratocumulus? Atmos. Chem. Phys. 12, 4567-4583 (2012)

71. Turner, D. D. et al. Thin liquid water clouds: Their importance and our challenge. Bull. Amer. Meteor. Soc. 88, 177-190 (2007).

72. Grabowski, W. W. et al. Daytime convective development over land: A model intercomparison based on LBA observations. Q. J. R. Meteorol. Soc. 132, 317-344 (2006).

73. Roehrig, R., Bouniol, D., Guichard, F., Hourdin, F. \& Redelsperger, J.-L. The present and future of the West African Monsoon: A process-oriented assessment of CMIP5 simulations along the AMMA Transect. J. Clim. 26, 6471-6505 (2013)

74. Couvreux, F. et al. Modelling of the thermodynamical diurnal cycle in the lower atmosphere: A joint evaluation of four contrasted regimes in the tropics over land. Bound. Layer Meteorol. 150, 185-214 (2014).

75. Storer, R. L. et al. Modeling aerosol impacts on convective storms in different environment. J. Atmos. Sci. 67, 3904-3915 (2010).
76. Jiang, H. \& Feingold, G. Effect of aerosol on warm convective clouds Aerosol-cloud-surface flux feedbacks in a new coupled large eddy model. J. Geophys. Res. 111, D01202 (2006).

77. Seifert, A., Köhler, C. \& Beheng, K. D. Aerosol-cloud-precipitation effects over Germany as simulated by a convective-scale numerical weather prediction model. Atmos. Chem. Phys. 12, 709-725 (2012).

78. Lee, S.-S. \& Feingold, G. Aerosol effects on the cloud-field properties of tropical convective clouds. Atmos. Chem. Phys. Discuss. 13, 2997-3029 (2013).

79. Marsham, J. H. et al. The role of moist convection in the West African monsoon system: Insights from continental-scale convection-permitting simulations. Geophys. Res. Lett. 40, 1843-1849 (2013).

80. Birch, C. E. et al. A seamless assessment of the role of convection in the water cycle of the West African monsoon. J. Geophys. Res. 119, 2890-2912 (2014).

81. Agustí-Panareda, A. et al. The ECMWF re-analysis for the AMMA observational campaign. Q. J. R. Meteorol. Soc. 136, 1457-1472 (2010).

82. Meynadier, R. et al. West African Monsoon water cycle: 2. Assessment of numerical weather prediction water budgets. J. Geophys. Res. 115, D19107 (2010)

83. Xue, Y. et al. Intercomparison and analyses of the climatology of the West African Monsoon in the West African Monsoon Modeling and Evaluation project (WAMME) first model intercomparison experiment. Clim. Dynam. 35, 3-27 (2010)

84. Philippon, N., Doblas-Reyes, F. J. \& Ruti, P. M. Skill, reproducibil ty and potentia predictability of the West African monsoon in coupled GCMs. Clim. Dynam. 35, 53-74 (2010).

85. Vellinga, M., Arribas, A. \& Graham, R. Seasonal forecasts for regional onset of the West African monsoon. Clim. Dynam. 40, 3047-3070 (2012).

86. Druyan, L. M. Studies of 21st-century precipitation trends over West Africa. Int. J. Climatol. 31, 1415-1424 (2011).

87. Paeth, H. et al. Progress in regional downscaling of West African precipitation. Atmos. Sci. Lett. 12, 75-82 (2011)

88. Christensen, J. H. et al. in Climate Change 2013: The Physical Science Basis (eds Stocker, T. F. et al.) 1217-1308 (IPCC, Cambridge Univ. Press, 2013).

89. Ruti, P. M. et al. The West African climate system: A review of the AMMA model inter-comparison initiatives. Atmos. Sci. Lett. 12, 116-122 (2011).

90. Gbobaniyi, E. et al. Climatology, annual cycle and interannual variability of precipitation and temperature in CORDEX simulations over West Africa. Int. J. Climatol. 34, 2241-2257 (2013).

91. Milton, S. F. et al. Modeled and observed atmospheric radiation balance during the West African dry season: Role of mineral dust, biomass burning aerosol, and surface albedo. J. Geophys. Res. 113, 1-24 (2008).

92. Garcia-Carreras. L. et al. The impact of convective cold pool outflows on model biases in the Sahara. Geophys. Res. Lett. 40, 1647-1652 (2013).

93. Brandt, P. et al. Equatorial upper-ocean dynamics and their interaction with the West African monsoon. Atmos. Sci. Lett. 12, 24-30 (2011).

94. Parker, D. J. et al. The AMMA radiosonde program and its implications for the future of atmospheric monitoring over Africa. Bull. Am. Meteorol. Soc. 89, 1015-1027 (2008)

95. Knippertz, P. et al. The DACCIWA project: Dynamics-aerosolchemistry-cloud interactions in West Africa. Bull. Am. Meteorol. Soc., http://dx.doi.org/10.1175/BAMS-D-14-00108.1 (2015).

96. Levy, R. C., Remer, L. A. \& Dubovik, O. Global aerosol optical properties and application to Moderate Resolution Imaging Spectroradiometer aerosol retrieval over land. J. Geophys. Res. 112, D13210 (2007).

97. H timana, L. et al. West African Futures - Settlement, Market and Food Security (OECD, 2011).

\section{Acknowledgements}

The research leading to these results has received funding from the European Union Seventh Framework Programme (FP7/2007-2013) under grant agreement 603,502 as part of the DACCIWA project. We thank M. Maranan for creating Fig. 1, and R. Redl and R. van der Linden for creating Fig. 2.

\section{Author contributions}

P.K. led the drafting of the text with input from the other authors on specific aspects. All authors contributed to the intellectual content.

\section{Competing financial interests}

The authors declare no competing financial interests. 
Karlsruher Institut für Technologie

\section{Repository KITopen}

Dies ist ein Postprint/begutachtetes Manuskript.

Empfohlene Zitierung:

Knippertz, P.; Evans, M. J.; Field, P. R.; Fink, A. H.; Liousse, C.; Marsham, J. H. The possible role of local air pollution in climate change in West Africa. 2015. Nature Climate Change, 5. doi: $\underline{10.5445 / I R / 110102665}$

Zitierung der Originalveröffentlichung:

Knippertz, P.; Evans, M. J.; Field, P. R.; Fink, A. H.; Liousse, C.; Marsham, J. H. The possible role of local air pollution in climate change in West Africa. 2015. Nature Climate Change, 5, 815-822. doi:10.1038/nclimate2727 